\title{
Supervision of School-Based, Agricultural Education: A Historical Review
}

\author{
Cassie M. Graham ${ }^{\mathrm{a}}$, M. Craig Edwards ${ }^{\mathrm{b}}$ \\ ${ }^{a}$ Garber Public Schools, ${ }^{b}$ Oklahoma State University
}

\begin{abstract}
This study's purpose was to understand the historical evolution of the supervision of school-based, agricultural education (SBAE). Supervision as a concept is described, including its emergence as an integral part of public school education in the United States. Moreover, the perspectives of early leaders of vocational education, such as Charles Prosser, are examined, as well as the impact of the Smith-Hughes Act of 1917 and other key federal legislation that came afterward. Supervision of SBAE as inspection and administrative oversight and for the purpose of instructional improvement is explored. We also discuss the early supervisory role of teacher educators of agricultural education; the ascendance and, in some cases, later decline of state staff as supervisors; and the role of local school administrators in the supervision of SBAE, including some of the philosophical tensions and divergent views among and between those stakeholders. Implications and recommendations are offered regarding the supervision of SBAE in the future, especially the role of professional organizations, such as the National Association of Agricultural Educators, the American Association for Agricultural Education, and the National Association of Supervisors of Agricultural Education, and their working in concert with The National Council for Agricultural Education.
\end{abstract}

Keywords: agricultural education, program supervision, supervisors, vocational education

\section{Introduction}

In 1917, vocational agricultural education faced a shortage of teacher educators (Hillison, 1999), and the existing professionals were in desperate need of assistance and support. In many cases, teacher educators provided supervision and oversight of local vocational agriculture programs in addition to fulfilling professional duties at their respective institutions (Anderson, Barrick, \& Hughes, 1992). It was at this critical juncture that the idea of state supervision for vocational agricultural education was first proposed (Hillison, 1999). Soon after, this idea became a reality as formal state supervision was mandated with the passage of the Smith-Hughes Act in 1917 (Herring, 1999). In its infancy, supervision was formal, strict, and oriented toward rules enforcement (Hillison, 1999). However, during the next few decades a slow but gradual shift occurred. Hillison (1999) concluded that the influence of state supervisors peaked in the 1960s. At that time, state supervisors had two major roles: supervision and inspection (Herring, 1999). This supervision and inspection model guided the oversight of departments of education in most states.

Supervision is defined in a variety of ways reflecting multiple fields' perspectives (Glatthorn, 1984). The idea of supervision is a necessity in "business, political, commercial, social religious or other enterprises in which group effort is to be directed toward a common goal” (Seimer, 1973, p. 6). Seimer (1973) defined supervision, in general, as "includ[ing the] combination of planning, organizing, directing, measuring, controlling, assembling resources, supervising, coordinating, motivating, commanding and integrating” (p. 3). Glatthorn (1984) proposed a broad definition of the act or actions as general supervision, i.e., a comprehensive approach versus clinical supervision or a direct approach.

Glatthorn (1984) described the direct approach to supervising a teacher's instructional practice as "a process of facilitating the professional growth of a teacher, primarily by giving the teacher feedback about classroom interactions and helping the teacher make use of that feedback in order to make teaching more effective” (p. 2). Glickman (1990) compiled a list of those typically considered supervisors in education such as "school principals, assistant principals, instructional lead teachers, department heads, master teachers, teachers, program directors, central office consultants and coordinators, and associate or assistant superintendents” (p. 6). Olivia (1993) further defined "supervision [as] a means of offering teachers specialized help in improving instruction” (p. 11)

\footnotetext{
คณก Creative Commons CC-BY-NC-ND: This article is distributed under the terms of the Creative Commons Attribution 4.0 License (http://creativecommons.org/licenses/by/4.0/) which allows others to download your works and share them with others as long as they credit you, but they can't change them in any way or use them commercially.
} 
presented in the context of "both individuals and in groups" (p. 11). Therefore,

[c]ollaboration and partnership between supervisors and teachers became important. Supervisors began to realize that their success was dependent more on interpersonal skills than on technical skills and knowledge; they had to become sensitive to the behavior of groups and individuals within groups. (Olivia, 1993, p. 9)

Moreover, " $[\mathrm{t}] \mathrm{o}$ put it simply, supervision is a means of offering to teachers specialized help in improving instruction" (Olivia, 1993, p. 11), and, according to Olivia (1993), "[e]xpanding curriculum revealed the need for specialists in instructional supervision” (p. 6). This need for supervisory oversight included schoolbased, agricultural education (SBAE).

During the first decades after enactment of the Smith-Hughes Act, a debate over who should be leading or supervising states' vocational agricultural education programs, and, therefore, providing oversight of teachers and departments, became a significant point of contention (Stewart, 1999). Arguments were offered for and against by teachers, teacher educators, state department officials, and other stakeholders, as different approaches to supervision were proposed. If state staff were expected to only oversee the "responsibility for funding, teacher placement, and program quality" (p. 6) and local school administrators were mostly responsible for supervising the quality of instruction provided by vocational agriculture teachers, the state supervisor's role might be criticized or even lack teachers' respect (Stewart, 1999). On the contrary, if state staff focused on providing instructional leadership for local programs, the need to expand their capacity would have been open to debate (Stewart, 1999). However, according to Roberts (1971) the primary goal of state supervision was to improve instruction. To that end, federal funding was established to promote and enhance the quality of SBAE programs in each state (Straquadine, 1990). Even though state supervisors became a norm for SBAE in a majority of states' education agencies or departments, these units experienced gradual reductions in staffing levels beginning in the 1980s (Stewart, 1999).

Nonetheless, the U.S. Department of Agriculture and the Department of Education were encouraged by Congress through the Agricultural Research, Extension and Education Reform Act of 1997 to work together to support SBAE (Case, 1999). Case (1999) explained: "It is the sense of Congress that the Secretary of Agriculture and the Secretary of Education should collaborate and cooperate in providing both instructional and technical support for school-based agricultural education” (p. 5), as mandated by Public Law 105-185 (S. 1151 Public Law 105-185). This position also implied the need to provide program supervision and oversight.

Early in the history of SBAE, decisions needed to be made regarding the role of state supervisors, as well as the qualifications for such positions (Hillison, 1999).
Many state supervisors, of what was then called vocational agricultural education, were required to have three to five years of teaching experience in that field (Swanson, 1940). However, little is known about how these individuals influenced SBAE, especially in its formative years. An important part of this story includes the relationships between supervisors and teacher educators of agricultural education as well as local school officials also responsible for supervising aspects of SBAE programs. This study sought to explore the historical roles and actions of those charged with supervising SBAE.

\section{Purpose and Research Questions}

This study's purpose was to examine the historical role of supervisors in SBAE. Three research questions guided this inquiry: 1. How was SBAE supervised before passage of federal legislation that mandated supervision by government agencies? 2. What key federal legislative acts formalized supervisory regulations and procedures for SBAE programs? 3. Were the philosophies of individuals charged with supervising SBAE unified or divergent over time?

\section{Methods}

Historical inquiry methods were used to address this study's research questions. McDowell (2002) proposed using historical evidence to understand the past and elaborated that the researcher's responsibility is to provide the best interpretation of events, as supported by primary and secondary sources. To further ensure this study met standards for rigor and trustworthiness, we also followed Tracy's (2010) recommendations for worthiness, rich rigor, sincerity, credibility, resonance, significant contribution, ethics, and meaningful coherence. We developed an outline of historical events presaging as well as fomenting the emergence and evolution of the supervision of SBAE over time. Primary sources used for this study included federal legislative acts, bulletins, and circulars. The study's secondary sources included peer-refereed journal articles, books, peer-reviewed magazine articles, and the website of a relevant professional organization. We relied on Internet search engines made available by the main library at Oklahoma State University as well as Google Scholar. Search terms included instructional leader; school-based, agricultural education; state supervisors; supervision; supervisors of teacher education; vocational agriculture(al) education; and vocational supervisors. All data sources were subjected to internal and external review by the researchers (McDowell, 2002). This was accomplished by examining multiple sources to triangulate findings and verify the authenticity and accuracy of such (McDowell, 2002; Tracy, 2010). Our aim was to produce a coherent, 
explanatory account of historical events and actors surrounding the phenomenon understudy.

\section{Findings}

\section{Research Question \#1 - How was SBAE supervised before passage of federal legislation that mandated supervision by government agencies?}

In regard to the formal enterprise of education, grammar schools were the first educational units for which supervision was required from authoritative figures, such as headmasters or headteachers (Gwynn, 1967; see Figure 1). "By 1721, visiting committees were being used to investigate the work [of teachers] in the Latin Grammar School” (Gwynn, 1967, p. 7). The school principal position emerged in 1821 with the further development of secondary education (Gwynn, 1967). "After 1827 this power [i.e., to oversee the school administratively] gradually became vested in a single person, a local superintendent, who was to administer and inspect the schools” (Gwynn, 1967, p. 5). In addition,

[w]ith the establishment of legal support for the secondary school (1874), and the passing of compulsory attendance laws which greatly increased secondary school attendance, experienced teachers were often used to supervise other teachers in the same subject fields; thus the position of department head as supervisor was created. (Gwynn, 1967, p.7)

Before passage of the Smith-Hughes Act of 1917, the idea of states' departments of education supervising SBAE programs was close to nonexistent (Hillison, 1999). Local school administrators, in most cases principals, provided the primary supervision of SBAE (Field, 1929). Hence, the need for administrative supervision of SBAE was identified before passage of the Smith-Hughes Act of 1917. As early as 1875, Payne asserted that, although the purpose and benefits of supervision were recognized in mechanical, trade, and government work environments, significant "reluctance [existed] to admit its value and necessity in the management of school systems” (p. 21). Payne (1875) further acknowledged the need for secondary education supervision and stated the importance of implementing supervisory roles in public schools: "A school system requires direction by one responsible head. - It is thus seen that the work of instruction follows the law which prevails in all other industries" (p. 17). In the context of the late 1800s in the United States, Payne (1875) defined the roles and characteristics of school supervisors:

To superintend the work of instruction with advantage requires, at least, considerable executive ability, a somewhat complete knowledge of the branches taught and ready skill in discipline. With these qualifications alone, a system of instruction may be kept from deterioration. (p. 19)
Early school supervisors were responsible for developing plans of study, classification of students, discipline procedures, teacher evaluations, and record keeping (Payne, 1875): "He [the supervisor] is to prepare plans of instruction and discipline, which the teachers must carry into effect; but the successful working out of such a scheme requires constant oversight and constant readjustments” (p. 76). The initial contributors to supervisory practice in regard to SBAE programs, such as Rufus Stimson, maintained that supervisors were responsible for two tasks, teacher training and state supervision (Moore, 1988). To this end, "Bawden [a vocational agriculture instructor] after his 1913 visit in Massachusetts, point[ed] out that Stimson's visits [to schools teaching agriculture] were not merely supervisory and inspectional but also furnished guidance and help for the teachers” (Moore, 1988, p. 14).

Initial federal funding to support vocational agricultural education began with the Nelson Amendment of 1907, which "provided federal support to land-grant universities to provide training for the purpose of teaching agricultural and mechanical arts" (Hillison, 1999, p. 57). After 1917 and enactment of the Smith-Hughes Act, the number of supervisors, in regard to specific subject areas, increased as a result of "compliance with the provisions of federal grants for vocational education, such as vocational home economics and agriculture and trades and industries" (Gwynn, 1967, p. 8). Regarding official oversight, "[e]arly inspectional services of state departments [of education], however, usually had their origin in the state university or in other institutions for higher education in the state or region” (Gwynn, 1967, p. 8).

Moreover, Charles Prosser (1918) asserted that supervision of vocational education emanated through the advancement of work and inspection with the continuation of program funding attached to the outcomes derived from conducting supervision. Nonetheless, Gwynn (1967) questioned the roles and responsibilities of early supervisors, and highlighted consequences associated with the lack of qualified supervisors in the education workforce. Gwynn (1967) maintained that "[t]he supervisor ... [was] no longer an inspector, however, for in the years since 1920, a number of broadened concepts of the supervisory role have gradually developed from the administrative function” (p. 3). Gwynn (1967) further stated: "Recognition must be given to the understanding of both the public and the professional educator as to the nature of both supervision and successful teaching” (p. 4). The supervisor's role prior to the Smith-Hughes Act and their roles in more contemporary times have shifted and evolved (Moore, 2006). 


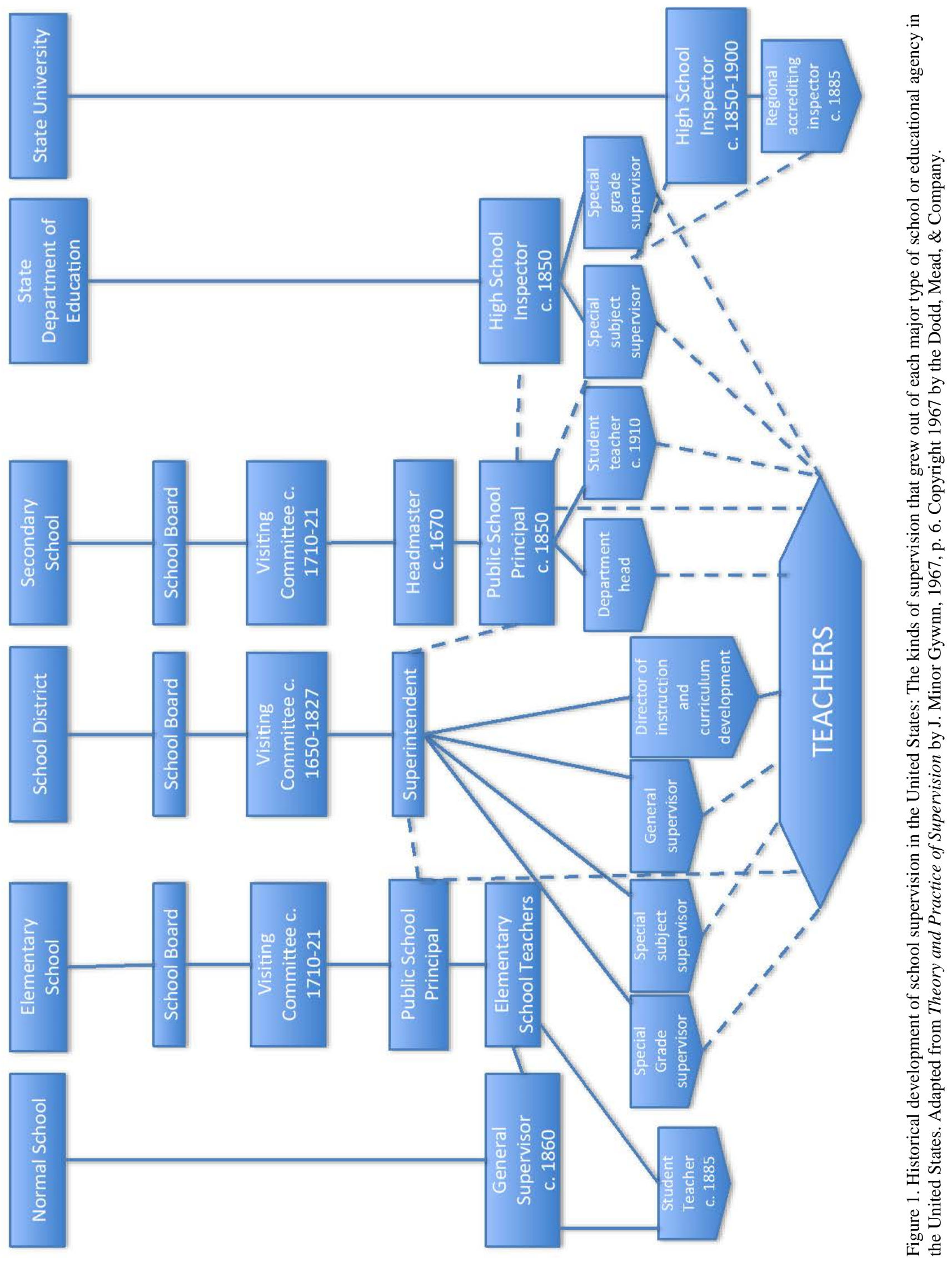




\section{Research Question \#2 - What key federal legislative acts formalized supervisory regulations and procedures for SBAE programs?}

The concept of formal, state-provided supervision for SBAE programs emerged as a result of the SmithHughes Act of 1917 and this approach to administrative oversight peaked in the 1960s (Hillison, 1999). It was through this act that federal funding was allocated to expand and sustain SBAE, as well as home economics and trade and industrial education, in public schools (Finch, 1999).

Under the vocational education act [of 1917] the Federal grant available each year for the promotion of vocational education in the States increase[d] . . . to the maximum of $\$ 7,167,000$ available in 192526 and annually thereafter. For each year that amounts shown as Federal grants must, if expanded, be matched dollar by dollar by State or local money, so that for any year the joint fund available, made up of Federal, State and local money, is double the Federal grant. This joint fund must be expanded for salaries of teachers and supervision [emphasis added] and for maintenance of teacher training. (U.S. Federal Board for Vocational Education, 1921, p. 10)

Prosser was a leading advocate for federal funding in regard to vocational education, and its administration; therefore, he should be recognized for his leadership toward "initiating the formal supervision of vocational teaching, academic teaching and teacher education" (Finch, 1999, p. 200). His influence guided much of the early mandates and actions to that end. According to the Federal Board for Vocational Education, nine incorporated responsibilities of the state supervisor of agricultural education were to guide his practice:

1. Supervision of all schools receiving Federal money for the salaries of teachers or supervisors of agricultural subjects.

2. The supervision of all other schools or departments of agriculture in the State meeting the standards set up by the State board and approved by the Federal Board, even though such schools are not to receive Federal aid.

3. The supervision of the training of teachers of agriculture.

4. Studying the agricultural conditions of the State and the school facilities of particular communities which seem best suited to the establishment of vocational schools or classes of agriculture.

5. The preparation from time to time of manuscripts for bulletins of information concerning the teaching of agriculture in schools or classes in State and the setting forth of the possibilities of such instruction.

6. The preparation of reports for the State board and concerning agricultural subjects.
7. Holding conferences of teachers engaged in the teaching of agricultural subjects.

8. Promoting in other ways of vocational agriculture in the State.

9. Assisting teachers of agriculture to improve their method of instruction. This improvement may be done by personal consultation, by conferences, by correspondence, and through publications. (Agricultural Education: Some Problems, 1918, p. 10)

The George-Deen Act of 1936 allotted 1.2 million dollars to support vocational education, which included funding for supervisor travel (National Association of Supervisors of Agricultural Education, 2015). Thereafter, the George-Barden Act of 1946 allowed funds to be used for the salaries of states' supervisors of vocational education, including state staff members providing oversight for vocational agricultural education (National Association of Supervisors of Agricultural Education, 2015).

The Vocational Education Act of 1963 would signal a significant philosophical shift and presage a changing approach to vocational education in the United States (Finch, 1999). In accord, Moore (2006) asserted that the "Vocational Education Act of 1963 diminished the power of the supervisors" (p. 2). The increased federal control of education, or that perception, was viewed negatively due to public doubts regarding the power of local education officials to resist such pressures (Keppel, 1966). In some cases, for example, local administrators attempted to balance school financing to meet community needs in a holistic way versus the delivery of exceptional special services (Keppel, 1966), which were being increasingly mandated. To this point, Anderson (1977) reported that local school officials voiced concerns about "a decline in quality and quantity of leadership at the state level due to the assignment of reduced authority and visibility to vocational directors by chief state school officers" (p. 8).

In 1977, Anderson indicated the financial support of and attention to vocational education had been a progressive trend that appeared to be continuing. State supervisors and teacher training faculty were given the responsibility of directing state programs of vocational education, including SBAE (Weiler, Hemp, \& Hensel, 1966, p. 12). In the late 1980s, however, states would begin requesting block grants to support their systems of vocational education. During this time, educational programs faced the possibility of consolidation.

In education, Title I of the Administration's bill would have repealed and consolidated four major education programs: Title I of the Elementary and Secondary Education Act (ESEA), the Education of the Handicapped Act, the Emergency School Aid Act, and the Adult Education Act. Title II proposed consolidation of virtually all other federal aid programs with the exception of bilingual education, 
impact aid, and vocational education. (Verstegen, 1990, p. 358)

Jennings (1991) also described a significant reorganization regarding the use of federal funds for vocational education in the United States:

Channeling federal money to programs that integrate academic and vocational education, targeting money more carefully toward programs that produce results, emphasizing programs that serve poor and otherwise disadvantaged people, and easing state regulatory burdens by pushing authority down to the local level. (p. 18)

Thereafter, "the Carl D. Perkins Career and Technical Education (CTE) Improvement Act was passed by Congress and signed into law by President Bush [in the fall of 2006]” (Threeton, 2007, p. 66). This act

focuse[d] on three of the roles and responsibilities found within legislation which include the title change to that of CTE, the inclusion of counselors and CTE instructors in the guidance and student development process and the integration of academics into career and technical curriculum. (Threeton, 2007, p. 66)

In response to the sweeping changes impacting CTE, Moore (2006) suggested that teacher educators of agricultural education should supplement federal legislative guidelines by providing leadership directed specifically toward programs and teachers of SBAE.

\section{Research Question \#3 - Were the philosophies of individuals charged with supervising SBAE unified or divergent over time?}

According to Gwynn (1967), “[s]upervision, one of the oldest forms of educational leadership, is currently one of the most controversial” (p. 3). Key actors occupy multiple leadership roles in the education system that, at times, express mutual respect for one another, and, at other times, may hold contrarian views about important issues (Keppel, 1966).

The programmatic views held by state supervisors, teacher educators, and instructors of SBAE may not always be aligned or congruent. For example, different opinions regarding the admission of girls to SBAE and solutions to teacher shortages were common (Weiler et al., 1966). As early as the 1870 s, Payne (1875) stated that educators are held accountable and responsible for quality instruction and classroom management all while implementing their own perspective of teaching methods fitting the evaluation paradigm. Moreover, Mosher and Purpel (1972) asserted that,

[t]he conflicting pressures on the school supervisor to teach; to work with student teachers and beginning teachers and to evaluate experienced teachers; to supervise across subject areas; to direct curriculum projects, and to discharge a host of administrative and clerical tasks, complicate the problem of defining the job. (pp. 2-3)
Historically, "a lack of skilled labor, and especially of that variety of labor which is most truly productive supervision [of the education enterprise]" was noted (Payne, 1875, p. 24). Nearly a century later, Mosher and Purpel (1972) described a longstanding issue in regard to teaching, learning, and educational outcomes:

We lack sufficient understanding of the process of teaching. Our theories of learning are inadequate, the criteria for measuring teaching effectiveness are imprecise, and deep disagreement exists about what knowledge - that is what curriculum - is most valuable to teach. There is no generally agreedupon definition of what teaching is or of how to measure its effects. (p. 3)

These deficits or uncertainties continue to impact suppositions and practices of instructional supervision as well as other aspects of educational administration and leadership. SBAE has not been immune to the controversies and contradictions surrounding such purposes, including how the program should be supervised and by whom. The role of program supervision and who should supervise often led to disagreements among key stakeholders of SBAE. To this point,

Dr. Melvin Barlow, writing in The 1974 AVA Yearbook, reminded us of the following: It is important to draw distinction between basic philosophical foundations and convenient administration decisions. The former are stable and the latter are more transient in quality. (as cited in Anderson, 1977, p. 3)

The unified responsibilities of state supervision manifested Prosser's (1918) views on the administrative supervision of vocational education:

I feel that our supervision and inspection must be, which would be pictured by a man holding large power in his hands (so far as the use of funds, for example, is concerned) that would be exercised and yet letting the leash loose as far as is necessary [and] consistent with the proper use of the funds and keeping the schools acting in good faith and headed in the right direction, constantly making improvements in their work. (p. 2)

Further, in regard to the responsibilities of state supervisors of SBAE, the supervisor must "render assistance to the teachers, and at the same time check up [on] their work" (Agricultural Education: Some Problems, 1918, p. 75). By the supervisor

[a]cting in this capacity, provided he is administering a system of education in which the state has responsibility for the success or conduct of a school, he is a policing officer charged with the duty of determining whether or not the school meets the standards set up for the state. (Agricultural Education: Some Problems, 1918, p. 12)

Anderson (1977) expressed his concern for standards fearing the loss of integrity and purpose of the vocational education program; in particular, the idea of 
looser quality program standards in exchange for higher student enrollment concerned him. Decades before, others had expressed concerns with the idea of transitioning supervisory control of SBAE from state education agency personnel to local school principals. For example, Hillison (1999) concluded:

The first concern was that principals had little time for supervision of instruction. The second concern was that frequently principals were young and inexperienced; often the agricultural teacher was more mature and more experienced. Thirdly, the agricultural education teacher had more education and background in agriculture than did the typical principal. (p. 58)

As the supervision of SBAE moved more into the hands of local school principals, in some cases, the aims of state supervision may have shifted to goals reflecting aspects of program achievement. To that end, Anderson (1977) asserted: "With rare exceptions, agricultural educators have tended to concentrate their efforts on those students who could win the largest number of awards or activities" (p. 4). Although the FFA organization enhanced the presence of SBAE programs to the public, that was coupled with increasing demands of time from teachers, state staff, and students (Hamlin, 1956). Such an emphasis may have ultimately impacted the way teachers of SBAE were prepared. Even further, Anderson (1977) essentially asked this question: Should programs that condone the "misuse of vocational resources and rewards vocational teachers who send many of their students to college, or win contests and awards, but place very few of their graduates in occupations for which they were trained" (p. 5) be considered weaker or inferior programs?

Career and technical education programs, including SBAE, are less likely to be supervised by persons who have such backgrounds, which may result in ineffective instructional leadership (Zirkle \& Cotton, 2001). As a result of the changing and weakening of state supervisors, some SBAE teachers turned to teacher educators for leadership advice (Hillison, 1998). Moore (2006) questioned from where the leadership for the agricultural education profession was emerging and who would be the driving force in the future: "At one time it was very clear who was driving the profession - state supervisors” (p. 1), but, arguably, at least in the case of many states, that is no longer true. Rather, "[t]eacher educators have assumed a greater role in the hiring process of teachers, as well as in the perennial battles with Congress and state legislatures" (Hillison, 1998, p. 6). Further, according to Hillison (1998):

[the] teacher educator [should be] one who [is] able to prepare future teachers and in-service current teachers, but do other things as well . . . including teach agricultural communications courses, work with cooperative extension agents, coordinate distance learning, work with rural sociologists, teach leadership courses, coordinate technology, and work with Agriculture in the Classroom. (p. 6)
Indeed, Hillison (1998) described a long and robust list of professional tasks and responsibilities for teacher educators of agricultural education with their involvement in program supervision notwithstanding.

In a study completed by Garton and Chung (1996), Joint State Staff of Missouri and first-year teachers identified and prioritized areas of importance for firstyear teacher inservice. (Joint State Staff implies state education agency personnel and teacher educators.) If comparing the inservice needs of the two groups, "the four highest rated inservice needs for beginning teachers, as perceived by the Joint State Staff, were included in the 13 highest rated inservice needs as prioritized by the beginning teacher" (Garton \& Chung, 1996, p. 57). Although those similarities emerged between the beginning teacher and the Joint State Staff, in general, the "ranking of the inservice needs as perceived by beginning agriculture teachers did not correspond with the rankings of the inservice needs as perceived by the Joint State Staff” (Garton \& Chung, 1996, p. 57). Some instances of is versus ought thinking and related philosophical differences may have been divulged by the study's findings. State supervisors, teacher educators, and teachers of SBAE should be encouraged to align their philosophical positions in regard to program aims and standards to increase the likelihood of meeting students' needs and expectations of employers or the postsecondary education institutions to which program graduates matriculate.

\section{Conclusions, Implications, and Discussion}

Teachers' experiences, beliefs, and efforts largely determine the success of SBAE programs, and teacher educators play a role in influencing the standards and practices implemented in local programs (Anderson, 1977). Gwynn (1967) reflected on the growth of U.S. education supervision in 1920; some of his points still resonate today:

1. Supervision originated as inspection of schools and continued with that as its major emphasis to about 1920.

2. Much overlapping of the responsibilities and duties of the administrator and the general supervisor communicated itself later to the office of the assistant superintendent or the special supervisor. Among educational writers and school administrators, there was still no clear-cut distinction between the administrative and supervisory responsibilities of the supervisor.

3. Because of the confusion among administrative and supervisory officers as to their authority, teachers on both elementary and high school levels did not know whose instructions to follow. For example, should teachers follow the suggestions of the principal? Or of the supervisor? 
4. Both educational theorists and practicing schoolmen were at variance as to the functions of supervision. Such disagreements were forcing educators to define and delimit supervision.

5. Both teachers and administrators agreed in two respects - that supervision should be more than inspection and that the improvement of instruction was one of its major tasks. (pp. 8-9)

Moreover, "supervision, regardless of how it is defined, involves talk between a teacher and a supervisor about teaching” (Mosher \& Purpel, 1972, p. 140). Further, "whatever the causes of these difference[s between stakeholders, including supervisors and teacher educators], there is need for an improved working relationship” (Anderson et al., 1992, p. 48).

Writing about state supervisors more than 50 years ago, Weiler et al. (1966) stated: "[W]e must increase and improve state professional staff for vocational education” (p.15). In addition, Weiler et al. (1966) specified six points addressing state education department personnel:

1. Variety of programs demand more supervision and leadership from the state level.

2. Someone must keep up to date on specialized programs. Delegation of responsibility is essential.

3. We are working with more groups and individuals, consulting committees, local school boards, colleges, area schools, etc. Contacts must be made, informational materials are needed.

4. New occupations are emerging.

5. Consider need for advanced study, research, sabbatical leave, instructional aids, etc.

6. Let's maintain continuity of leadership by locating and employing younger people into state positions. (p. 15)

In the second decade of the 21st century, these points still resonate as well as many other issues and challenges likely to impact the future of SBAE. If the goals of state supervisors and teacher educators of agricultural education are to prepare and support teachers who, in turn, develop students for employment in the agricultural sector and its allied industries, or for postsecondary education, candid discussions about priorities and expectations should be ongoing. To this aim, nearly four decades ago, Anderson (1977) argued for less "FFA training [leading to] future mayors, councilmen, legislators, governors, and congressmen and [more] emphasis [on] evaluating percentage of past FFA members employed ... [in] less than college level" (p. 6) jobs or careers supporting the agricultural sector. Anderson's (1977) position notwithstanding, rapidly advancing technology coupled with an increasingly globalized economy would appear to support the need for more students to receive postsecondary education and training than he may have envisioned.
Four decades ago, Stewart, Shinn, and Richardson (1977) concluded supervisors and teacher educators shared a concern to improve the identity of agricultural education with the goal of recruiting and retaining highly effective teachers. A sustained teacher shortage today continues to echo their position. Almost 30 years later, Moore (2006) spoke to the ongoing shortage of agricultural education teachers and suggested that teacher educators of agricultural education provide leadership through their preservice programs. The concerns of Stewart et al. (1977) and Moore (2006) still stand today and have implications for a modern approach to the supervision of SBAE.

\section{Recommendations}

To recruit and retain highly effective teachers of SBAE, teacher educators must prepare future practitioners to address the learning needs of today's students through collaborations with fellow school colleagues (Darling-Hammond, 2006), including the professionals who supervise or oversee their efforts. Anderson et al. (1992) suggested "more frequent contact with teachers and administrators by teacher educators and State Division of Vocational Education personnel is needed in order to keep in touch with the current school situation” (p. 48). However, in the current era, extensive supervision by state education agency officials is little more than a distant memory in many states (Barrick, 2015; Herring, 1999; Moore, 2006). Nonetheless, "because of increased public demand for teacher accountability and technical advancements in the occupational areas of vocational programs, vocational teacher professional development has never been more important” (Anderson et al., 1992).

Although written 25 years ago, the position of Anderson et al. (1992) should still garner our attention. School-based, agricultural educators, university agricultural educators, and program supervisors of SBAE have a responsibility to provide leadership in furthering the profession. University faculty should collaborate with state supervisors, where the latter exist, to provide meaningful and relevant professional development and leadership to preservice agricultural educators and inservice SBAE teachers such that standards and accountability are supported and maintained. In states where state staff do not exist or their capacity is insufficient, university agricultural educators coupled with teacher organization leaders should unite to fill the supervisory void. In some states, this appears to have occurred (or is occurring) organically but it is likely that much more remains to be done.

For SBAE to continue to thrive, instructors, teacher educators, and state staff must strive to guide change by exerting leadership, individually and collectively, including through their respective professional organizations, i.e., the National Association of Agricultural Educators, the American Association for 
Agricultural Education, and the National Association of Supervisors of Agricultural Education. The National Council for Agricultural Education and its Team AgEd initiative (Barrick, 2015) should serve as the convener for guiding and facilitating such efforts.

\section{References}

Agricultural Education: Some Problems in State Supervision. (1918). Federal Board for Vocational Education, Bulletin No. 26. Washington, DC: Government Printing Office.

Anderson, H. (1977). An over the shoulder look at the contemporary philosophy and standards in vocational agriculture. Journal of the American Association of Teacher Educators in Agriculture, 18(1), 1-8. https://doi.org/10.5032/jaatea.1977. 01001

Anderson, T. J., Barrick, R. K., \& Hughes, M. (1992). Responsibilities of teacher education for vocational teacher professional development programs. Journal of Agricultural Education, 33(2), 43-50. https://doi.org/10.5032/jae.1992.02043

Barrick, K. R. (2015) Reflecting on new directions for agricultural education. The Agricultural Education Magazine, 88(3), 11-13.

Case, L. (1999). Is federal supervision of agricultural education needed in the 21st century? The Agricultural Education Magazine, 71(6), 4-5.

Darling-Hammond, L. (2006). Constructing 21st century teacher education. Journal of Teacher Education, 57(3), 300-314. https://doi.org/10.1177/ 0022487105285962

Field, A. M. (1929). An evaluation of certain phases of theory and practice in supervision of instruction in vocational agriculture with a suggestive program for improvement. Unpublished doctoral dissertation, Cornell University, Ithaca, NY.

Finch, C. (1999). Vocational education. In A. Pautler (Ed.), Workforce education issues for the new century (pp. 199-209). Ann Arbor, MI: Prakken.

Garton, B. L., \& Chung, N. (1996). The inservice needs of beginning teachers of agriculture as perceived by beginning teachers, teachers educators, and state supervisors. Journal of Agricultural Education, 37(30), 52-58. https://doi.org/10.5032/jae.1996. 03052

Glatthorn, A. (1984). Differentiated supervision. Alexandria, VA: Association for Supervision and Curriculum Development.

Glickman, C. D. (Ed.). (1990). Supervision of instruction: A developmental approach. Needham Heights, MA: Allyn and Bacon.

Gwynn, J. M. (1967). Theory and practice of supervision. New York, NY: Dodd, Mead, \& Company.

Hamlin, H. M. (1956). Fifty years of progress in agricultural education. American Vocational Journal, 31(9), 39-46.
Herring, D. R. (1999). Is state supervision of agricultural education needed in the 21st century? A teacher educator's perspective. The Agricultural Education Magazine, 71(6), 12-21.

Hillison, J. (1998). The role of the agricultural education teacher educator yesterday, today, and tomorrow. Journal of Agricultural Education, 39(1), 1-7. https://doi.org/10.5032/jae.1998.01001

Hillison, J. (1999). Whatever happened to the supervisor of the Smith-Hughes man? Journal of Agricultural Education, 40(2), 55-63. https://doi.org/10.5032/ jae.1999.02055

Jennings, J. F. (1991). Congressional intent. The House's legal expert on vocational education explains what Congress wants the Perkins Act to do. Vocational Education Journal, 66(2), 18-19.

Keppel, F. (1966). The necessary revolution in American education. New York, NY: Harper \& Row.

McDowell, W. H. (2002). Historical research: A guide. New York, NY: Routledge.

Moore, G. E. (1988). The forgotten leader in agricultural education: Rufus W. Stimson? The Journal of the American Association of Teacher Educators in Agriculture, 29(3), 50-58. https://doi.org/10.5032/ jaatea.1988.03051

Moore, G. E. (2006). Who is driving the pickup truck? A call for professional leadership. Journal of Agricultural Education, 47(1), 1-5. https://doi.org/ 10.5032/jae.2006.01001

Mosher, R. L., \& Purpel, D. E. (1972). Supervision: The reluctant profession. New York, NY: Houghton Mifflin Company.

National Association of Supervisors of Agricultural Education. (2015). About The National Association of Supervisors of Agricultural Education (NASAE). Retrieved from https://www.ffa.org/thecouncil/ nasae

Olivia, P. F. (Ed.). (1993). Supervision for today's schools. White Plains, NY: Longman Publishing Group.

Payne, W. H. (1875). Chapters on school supervision. New York, NY: Wilson, Hinkle \& Co.

Prosser, C. (1918). Policy of supervision under the Smith-Hughes Act. The Vocational Summary, 1(3), 2. Retrieved from https://babel.hathitrust.org/cgi/ pt?id=iau.31858050576069; view=1up;seq=44;size $=125$

Roberts, R. W. (1971). Vocational and practical arts education: History, development and principles. New York, NY: Harper and Row.S. 1151 Public Law 105-185. Title VI-Miscellaneous Provisions, Subtitle D-Senses of Congress.

Seimer, S. J. (1973). Elements of supervision. Columbus, OH: Grid, INC.

Stewart, M. (1999). How to make it work not why it will not work. The Agricultural Education Magazine, 71(6), 6-7. 
Stewart, B. R., Shinn, G. C., \& Richardson, W. B. (1977). Concerns of the agricultural education profession: Implications for teacher education. Journal of the American Association of Teacher Educators in Agriculture, 18(3), 19-26. https://doi.org/10.5032/jaatea.1977.03019

Straquadine, G. (1990). Current and expected roles in supervising agricultural science and technology programs in Utah. Paper presented at the annual convention of the American Vocational Association, Cincinnati, $\mathrm{OH}$. Abstract retrieved from https://files.eric.ed.gov/fulltext/ED328741.pdf

Swanson, H. B. (1940). The state and the preservice preparation of teachers of vocational education. Vocational Division Bulletin No. 219, U.S. Office of Education, Washington, DC: Government Printing Office.

Threeton, M. D. (2007). The Carl D. Perkins and Career and Technical Education (CTE) Act of 2006 and the roles and responsibilities of CTE teachers and faculty members. At Issue, 44(1), 66-82. Retrieved from https://files.eric.ed.gov/fulltext/EJ830476.pdf
Tracy, S. J. (2010). Qualitative quality: Eight “big-tent” criteria for excellent qualitative research. Sage, 16(10), 837-851. https://doi.org/10.1177/ 1077800410383121

U.S. Federal Board for Vocational Education. (1921). Vocational Summary, 3(11). Author, University of Michigan.

Verstegen, D. (1990). Education fiscal policy in the Reagan administration. Educational Evaluation and Policy Analysis, 14(4), 355-373. https://doi.org/ 10.3102/01623737012004355

Weiler, W., Hemp, P., \& Hensel, J. (1966). Implementing the vocational education act of 1963. Central States Seminar on Agricultural Education. Chicago, IL. Retrieved from https://files.eric.ed.gov/fulltext/ED010785.pdf

Zirkle, C. Z., \& Cotton, S. C. (2001). Where will future leadership come from? On the status of career \& technical education administration. Tech Directions, 61(5), 15. 